\title{
Early life of an inshore population of West Greenlandic cod Gadus morhua: spatial and
} temporal aspects of growth and survival

\author{
Swalethorp, Rasmus; Nielsen, Torkel Gissel; Thompson, A. R.; Møhl, Malene; Munk, Peter
}

Published in:

Marine Ecology - Progress Series

Link to article, DOI:

$10.3354 /$ meps 11816

Publication date:

2016

Document Version

Publisher's PDF, also known as Version of record

Link back to DTU Orbit

Citation (APA):

Swalethorp, R., Nielsen, T. G., Thompson, A. R., Møhl, M., \& Munk, P. (2016). Early life of an inshore population of West Greenlandic cod Gadus morhua: spatial and temporal aspects of growth and survival. Marine Ecology Progress Series, 555, 185-202. https://doi.org/10.3354/meps11816

\section{General rights}

Copyright and moral rights for the publications made accessible in the public portal are retained by the authors and/or other copyright owners and it is a condition of accessing publications that users recognise and abide by the legal requirements associated with these rights.

- Users may download and print one copy of any publication from the public portal for the purpose of private study or research.

- You may not further distribute the material or use it for any profit-making activity or commercial gain

- You may freely distribute the URL identifying the publication in the public portal 


\title{
Early life of an inshore population of West Greenlandic cod Gadus morhua: spatial and temporal aspects of growth and survival
}

\author{
Rasmus Swalethorp ${ }^{1,4, *}$, Torkel Gissel Nielsen ${ }^{1,2}$, Andrew R. Thompson ${ }^{3}$, \\ Malene Møhl ${ }^{1}$, Peter Munk ${ }^{1}$ \\ ${ }^{1}$ National Institute of Aquatic Resources (DTU Aqua), Section for Section for Marine Ecology and Oceanography, \\ Technical University of Denmark, Kavalergården 6, 2920 Charlottenlund, Denmark \\ ${ }^{2}$ Greenland Climate Research Centre, Greenland Institute of Natural Resources, Kivioq 2, PO Box 570, 3900 Nuuk, \\ Greenland \\ ${ }^{3}$ NOAA Fisheries Service, Southwest Fisheries Science Center, 8901 La Jolla Shores Drive, La Jolla, CA 92037-1508, USA \\ ${ }^{4}$ Present address: Scripps Institution of Oceanography, University of California, 9500 Gilman Drive, La Jolla, \\ CA 92093-0218 USA
}

\begin{abstract}
Understanding the processes that affect fish larval survival and recruitment is a fundamental tenant of fisheries science. Small, isolated fjords are ideal study systems for elucidating early life history processes, as population dynamics are well traced in these partially closed systems. We examined the distribution, growth and mortality of eggs and larvae of a fjord population of cod during a 5 mo field campaign in the fjord Kapisigdlit, West Greenland. Cod mainly spawned early in the season in the innermost shallow region of the fjord. Egg survival was generally high in the fjord. The high survival may have been driven by relatively high temperature and/or low predation in the inner region. Early in the season, the distribution of eggs and young larvae was mostly restricted to the spawning area. Later in the season, larger larvae had become more evenly distributed in the fjord. This shift in distribution was observed after the seasonal pulse in freshwater outflow following the ice break-up in Kapisigdlit River. There was a positive correlation between the amount of food in a larval stomach and growth, and larval growth was greater in the outer fjord where prey availability was higher. The timing between spawning and freshwater input may be essential for survival and recruitment, this ensuring low dispersal of eggs and younger stages and high dispersal of older, actively feeding stages. Therefore, cod in this area could be vulnerable to future climate change affecting the timing and magnitude of freshwater outflow, by changes in precipitation, temperature or prey availability.
\end{abstract}

KEY WORDS: Ichthyoplankton abundance $\cdot$ Otolith growth $\cdot$ Arctic $\cdot$ Annual egg production · Spawning stock biomass

Resale or republication not permitted without written consent of the publisher-

\section{INTRODUCTION}

Reproductive strategies of fishes have evolved to ensure that spawning and progeny development takes place when and where conditions are favorable to larval growth, survival and ultimately recruitment (Cushing 1990). Unlimited dispersal of eggs and larvae challenges the population connectivity, and low- dispersive environments, such as fjords and embayments, may facilitate the maintenance of self-seeding populations through retention of early life stages (Hastings \& Botsford 2006, Espeland et al. 2007, Bradbury et al. 2008). For instance, local populations of Atlantic cod Gadus morhua with inshore spawning grounds have been documented in Norway (Jakobsen 1987, Knutsen et al. 2007, Nordeide et al. 2011), 
Canada (Robichaud \& Rose 2004, Wroblewski et al. 2005) and Greenland (Hansen 1949, Smidt 1979, Storr-Paulsen et al. 2004). Often the inshore areas have a shallow entrance to the spawning area (Knutsen et al. 2007), which might promote retention of the early pelagic life stages of fish by reducing water exchange between the fjord and the outer sea. Indeed, observed genetic differences among fjord populations of cod separated by small distances (e.g. $30 \mathrm{~km}$ ) indicate very limited inter-fjord mixing between populations (Knutsen et al. 2003, Jorde et al. 2007). Despite the importance of local fjord populations in the meta-population structure of several important fish species, little is currently known about the reproductive strategies involved and the processes that affect egg and larval survival in these systems (Wroblewski et al. 2005, Knutsen et al. 2007).

West Greenlandic offshore populations of cod have shown large fluctuations during the 20th century and have now almost disappeared (Storr-Paulsen et al. 2004). Similarly, the Canadian offshore population of cod collapsed, and the decline was attributed to both high fishing pressure and climate variations (Rose et al. 2000, Buch et al. 2004, Stein \& Borovkov 2004). Inshore populations of West Greenlandic cod have also experienced large fluctuations in population size, but they have managed to persist in the restricted areas of distribution (Buch et al. 1994, Engelstoft 1997, ICES 2013, Bonanomi et al. 2015). The inshore and coastal populations are relatively small in size, but they are more numerous than those spawning offshore. A recent study compiling more than 500 publications found that of the 174 Atlantic cod populations studied $57 \%$ were coastal or inshore and most (63\%) displayed high spawning site fidelity (Robichaud \& Rose 2004). Fjords may offer stable and predictable conditions for growth and survival of early life stages, such as optimal temperature and prey availability and a moderate drift due to the geographical restriction and weak currents.

Early studies on Atlantic cod egg distributions showed that the Godthåbsfjord system harbors the largest inshore population of Atlantic cod in West Greenland (Hansen 1949, Smidt 1979). These studies identified the fjord branch Kapisigdlit as a principal spawning site for cod, where the shallow, innermost section of the fjord contained the highest egg densities observed along the entire west coast. To improve our understanding of the processes that govern the survival of early life stages of fish in such Arctic fjords, and ultimately determine the size of the adult populations, we set up an investigation of the key characteristics of the early life of cod in this fjord. The overall goal was to clarify in what way the specific characteristics of the fjord are beneficial for cod larval feeding and growth, and hence provide comparative information for furthering our understanding of the population dynamics of the species. A set of questions guided our research: (1) How is the spatio-temporal distribution of cod eggs and larvae linked to the oceanography in the fjord? (2) Do physical dispersal characteristics impact egg development and larval growth, potentially leading to enhanced survival? and (3) To what extent do temperature and prey availability affect larval growth? To put this locally important inshore population into the overall context of cod populations, we also used our investigation to provide an estimate of the spawning stock biomass (SSB).

\section{MATERIALS AND METHODS}

\section{Study site}

Sampling was conducted from 24 March to 5 August 2010 in the fjord branch Kapisigdlit located in the inner part of the Godthåbsfjord system, West Greenland. The vessel 'Lille Masik' was used during all cruises, except on 17-18 June when sampling was done from RV 'Dana' (National Institute for Aquatic Resources, Denmark). A total of 15 cruises (of 1-2 d duration) 7-10 d apart were carried out along a transect of 6 stations, spanning the length of the 26$\mathrm{km}$-long fjord branch. Stn 1 was located at the mouth of the fjord branch and Stn 6 at the end of the fjord branch, in the middle of a shallower inner creek (Fig. 1, Table 1). Stns 1-4 covered deeper parts of the fjord (Table 1), and Stn 5 was located on the slope leading up to the shallow inner creek.

\section{Hydrography}

Vertical profiles of water temperature, salinity and water density were recorded by CTD casts (SBE 19 plus or 911 plus SeaCat, and a SBE 25 SM MicroCat) down to approximately $15 \mathrm{~m}$ above the sea floor. The CTDs were calibrated against each other and against salinity samples collected with a Niskin bottle at 1, $10,20,50,75,100,150$ and $250 \mathrm{~m}$ depth on 24 May and 6 July and analyzed on a Portosal salinometer. A ship-mounted $600 \mathrm{kHz}$ acoustic Doppler current profiler (RD Instruments $\left.{ }^{\circledR}\right)$ was used to assess vertical profiles of water currents during 3 tidal cycles between 17 and 19 June at Stn 4 . Water flow rate was averaged for every $8 \mathrm{~m}$ strata at the surface and for every $16 \mathrm{~m}$ strata in the remaining water column. 


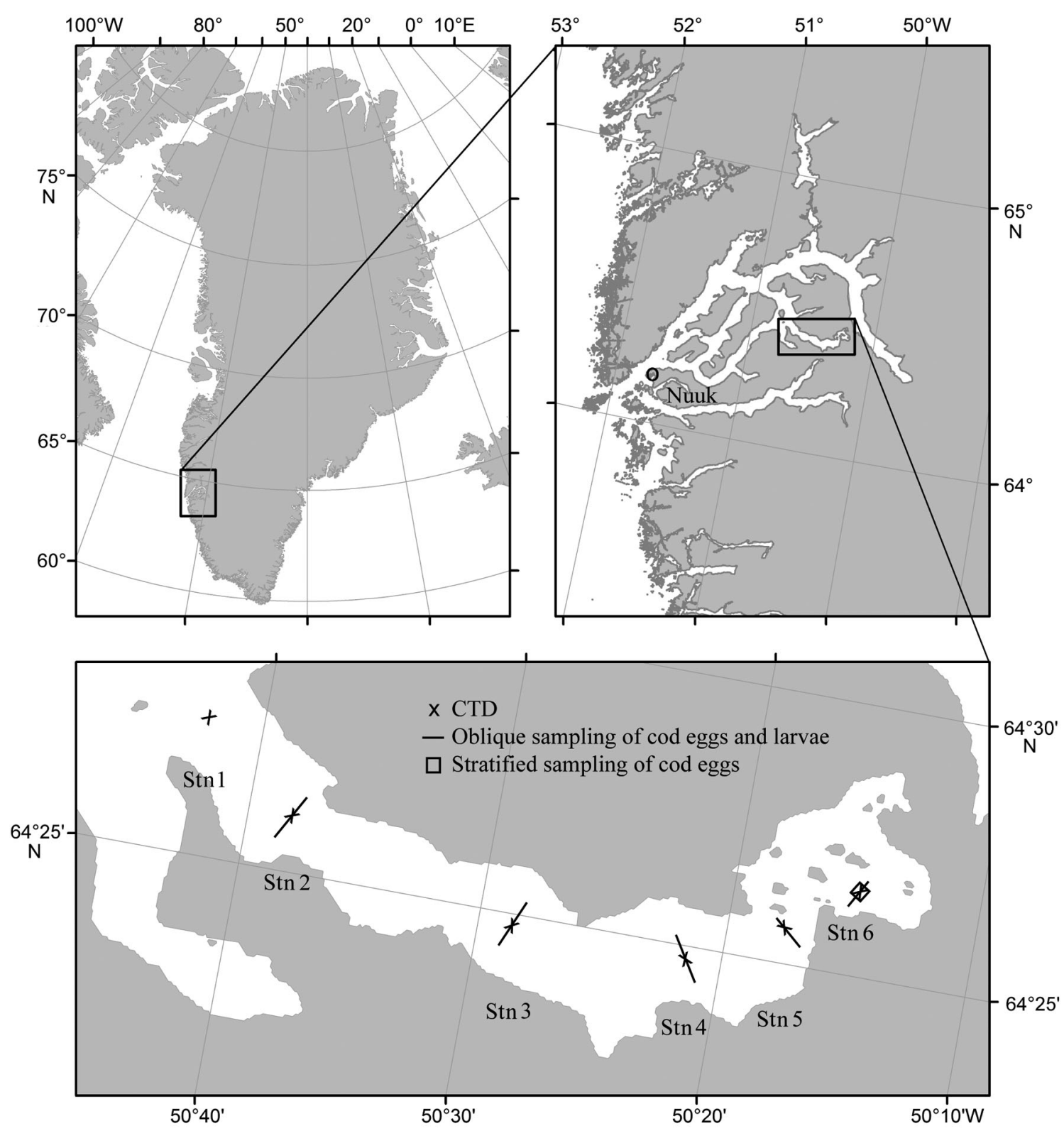

Fig. 1. Locations of sampling stations on the transect covering the length of the fjord branch Kapisigdlit

\section{Fish eggs and larvae}

Fish eggs and larvae were collected from Stns 2-6 using a Bongo net (2 circular rings of $60 \mathrm{~cm}$ diameter with mounted open nets of 300 and $500 \mu \mathrm{m}$ mesh size, 135-1150 $\mathrm{m}^{3}$ sample volume) from 24 March to 5 July. Subsequent sampling was carried out with a MIK ring net (ring of $2 \mathrm{~m}$ diameter and a $14 \mathrm{~m}$ long white open net of $600 \mu \mathrm{m}$ mesh size, $2027-20240 \mathrm{~m}^{3}$ sample volume). Both net types were fitted with a flow meter and a CTD (MicroCat SBE 25 SM) to record the flow of water into the net and haul profiles. Oblique net tows were conducted at a ship speed of 1.6 knots from the surface down to $100 \mathrm{~m}$ depth at most stations, but to $35-50 \mathrm{~m}$ above the sea floor at the 2 innermost stations due to shallow depths and uneven bathymetry (Table 1). Sampling at Stn 6 on 18 June was done with a vertical towed WP-2 net (200 $\mu \mathrm{m}$ mesh size, $14 \mathrm{~m}^{3}$ sample volume) and the larvae were preserved in ethanol (95\% final conc.). Bongo net samples were preserved in buffered formalin (the $300 \mu \mathrm{m}$ net, $4 \%$ final conc.) and in ethanol (the $500 \mu \mathrm{m}$ net, min. $50 \%$ final conc.). MIK net samples were split in 2 subsamples, one preserved in formalin and one in ethanol. Occasionally, MIK net samples were too large to preserve in full, 
Table 1. Station, distance from the fjord opening, locations, depths and location names. NS = no samples

\begin{tabular}{|lccccc|}
\hline $\begin{array}{l}\text { Stn } \\
\text { no. }\end{array}$ & $\begin{array}{c}\text { Distance } \\
(\mathrm{km})\end{array}$ & $\begin{array}{c}\text { Area } \\
\text { name }\end{array}$ & $\begin{array}{c}\text { Latitude, } \\
\text { Longitude }\end{array}$ & $\begin{array}{c}\text { Station } \\
\text { depth }(\mathrm{m})\end{array}$ & $\begin{array}{c}\text { Net sampling } \\
\text { depth }(\mathrm{m})\end{array}$ \\
\hline 1 & 0 & Outer fjord & $64^{\circ} 27^{\prime} \mathrm{N}, 50^{\circ} 42^{\prime} \mathrm{W}$ & 212 & $\mathrm{NS}$ \\
2 & 4.1 & Outer fjord & $64^{\circ} 26^{\prime} \mathrm{N}, 50^{\circ} 39^{\prime} \mathrm{W}$ & 194 & 100 \\
3 & 13.1 & Outer fjord & $64^{\circ} 25^{\prime} \mathrm{N}, 50^{\circ} 29^{\prime} \mathrm{W}$ & 230 & 100 \\
4 & 17.9 & Outer fjord & $64^{\circ} 25^{\prime} \mathrm{N}, 50^{\circ} 22^{\prime} \mathrm{W}$ & 251 & 100 \\
5 & 21.2 & Slope & $64^{\circ} 25^{\prime} \mathrm{N}, 50^{\circ} 18^{\prime} \mathrm{W}$ & 125 & 75 \\
6 & 24.1 & Inner creek & $64^{\circ} 26^{\prime} \mathrm{N}, 50^{\circ} 15^{\prime} \mathrm{W}$ & 85 & 50 \\
\hline
\end{tabular}

in which case a subsample was preserved and the remaining part kept cold $\left(\sim 5^{\circ} \mathrm{C}\right)$ and inspected for fish larvae within $48 \mathrm{~h}$ of sampling. All fish larvae found in the refrigerated part were then preserved in $95 \%$ ethanol. A specific study of the vertical distribution of fish eggs was carried out on 10 and 24 May and 3 June at Stn 6 in 5 depth strata $(0-10,10-20,20-30$, $30-40,40-50 \mathrm{~m}$ ) using a MultiNet (50 $\mu \mathrm{m}$ mesh size, Hydrobios mini) hauled vertically at $0.2-0.3 \mathrm{~m} \mathrm{~s}^{-1}$. Samples were immediately preserved in buffered formalin (4\% final conc.).

Fish eggs from all samples preserved in formalin were counted and the diameter of a maximum of 100 eggs per sample was measured and corrected for shrinkage due to formalin preservation ( $7 \%$, Hiemstra 1962). In 16 samples with high egg densities, a subsample (between 1/2 and 1/128) was taken using a Folsom plankton splitter. Egg development stages were determined for the measured eggs following the descriptions by Thompson \& Riely (1981). Only a few stage 1A eggs (visible cellular mass) were positively identified and these were therefore grouped together with stage 1B eggs (visible blastodisc). Eggs in the size range 1.15 to $1.73 \mathrm{~mm}$ (Ouellet et al. 2001) were assumed to be Atlantic cod Gadus morhua, as this species was the only one present with pelagic eggs within this size range, and Atlantic cod larvae emerged at the time when these eggs disappeared from the water column. Furthermore, this assumption was supported by examination of stage 5 eggs in this size range, in which the embryos had pigmentation characteristic of cod. In total, 7439 eggs were counted in the sample aliquots that were sorted, and out of the 3140 measured, 1510 were identified as Atlantic cod eggs.

All fish larvae were sorted and identified to genus or species level under a dissecting microscope. Standard lengths of Atlantic cod larvae (up to 40 per sample) were measured to the nearest $0.2 \mathrm{~mm}$. In total, 705 out of the 1257 sorted larvae were measured. Before measurement, cod larvae were soaked in fresh- water for approximately 2 min to minimize larval bending due to preservation. Standard lengths were corrected for shrinkage due to handling and preservation following Theilacker (1980):

$$
\ln (L)=\ln X_{1}+0.289 \mathrm{e}^{-0.434 X_{1} \cdot X_{2}{ }^{-0.68}}
$$

where $L$ is the standard length (mm) prior to handling and preservation, $X_{1}$ is the standard length of the preserved larvae $(\mathrm{mm})$ and $X_{2}$ is the time from death to fixation (which was set at $20 \mathrm{~min}$ ).

Due to differences in sampling depth between stations (Table 1), abundances of eggs and larvae were calculated per $\mathrm{m}^{2}$ based on net area, water flow and depth of the haul. Total abundances of cod eggs and larvae were calculated for the 5 sample stations. Egg abundances were extrapolated to 5 different geographical areas with the sampling stations at the center. The border between areas was defined as the halfway point between stations. Stn 2 was also assumed to represent half the area between that and Stn 1, and Stn 6 was assumed to represent the entire inner creek area. As the major part of the inner creek is shallower than $\operatorname{Stn} 6$, we assumed that $3.1 \mathrm{~km}^{2}$ is $\geq 50 \mathrm{~m}$ deep, $8.15 \mathrm{~km}^{2}$ is approximately $30 \mathrm{~m}$ deep and $7.65 \mathrm{~km}^{2}$ is approximately $10 \mathrm{~m}$ deep. The 10 and 30-m-deep areas were then assumed to contain 20 and $60 \%$ of the eggs and larvae, respectively, compared with Stn 6. As no bathymetric maps exist, the areas were calculated based on topographic observations by L. Heilmann, Greenland Institute of Natural Resources (pers. comm.). Calculations of the number of spawning females or spawning stock biomass (SSB) were based on unpublished data by R. Hedeholm, who in Kapisigdlit in 2007-2011 found the average female and male weight to be $1.65 \mathrm{~kg}$ $(\mathrm{n}=319)$ and $1.64 \mathrm{~kg}(\mathrm{n}=672)$, respectively, and fecundity to be 817200 eggs female ${ }^{-1}$. The average percentage of females was $32 \%(n=991$, R. Hedeholm unpubl. data).

\section{Egg development, production and mortality}

The average cod egg development time was calculated following Thompson \& Riely (1981):

$$
\ln (D)=A \cdot T+B
$$

where $D$ is the development time (d) from fertilization to the end of stage $5, T$ is the temperature $\left({ }^{\circ} \mathrm{C}\right)$, and $A$ 
and $B$ are regression coefficients of -0.1 and 3.46 , respectively. Mean development time was calculated using the average temperature from the main spawning period between 30 April to 3 June within the upper $30 \mathrm{~m}$ of the water column. The daily egg production (EP) was calculated as:

$$
\mathrm{EP}=A_{\text {Stage1 }} / D_{\text {Stage } 1 B}
$$

where $A_{\text {Stage } 1}$ is the abundance of stage $1 \mathrm{~A}+1 \mathrm{~B}$ eggs on the day of sampling and $D_{\text {Stage1B }}$ is the development time (d) from fertilization to the end of stage 1B calculated from the average temperature within the upper $30 \mathrm{~m}$ on the day of sampling. We assumed no mortality during this period. Coefficients $A$ and $B$ for stage 1B were -0.11 and 1.96 , respectively (Thompson \& Riely 1981). The annual egg production (AEP) was calculated following Armstrong et al. (2001) by integrating EP over the study period at intervals of $4-18 \mathrm{~d}$ depending on the time between cruises.

Egg mortality was expressed as the percentage of the AEP that did not survive until egg stage $4+5$. Stages 4 and 5 eggs were pooled to improve the estimate as very few were found at the outer Stns 2, 3 and 4. Egg mortalitywas calculated as:

$$
\text { Mortality }=100-\left(\mathrm{AEP}_{\text {Stage } 4+5} /\left(\mathrm{AEP}_{\text {Stage } 1} \cdot 100\right)\right)
$$

where $\mathrm{AEP}_{\text {Stage1 }}$ is the annual egg production calculated from stage 1 eggs as described above, and $\mathrm{AEP}_{\text {Stage } 4+5}$ is calculated from stage $4+5$ eggs using Eq. (3), where $D_{\text {Stage } 4+5}$ is the development time from the end of stage 3 to the end of stage 5 calculated from the average temperature within the upper $30 \mathrm{~m}$ on the day of sampling. The daily egg mortality $(Z)$ was then calculated as:

$$
Z=\frac{\ln \left(\mathrm{AEP}_{\text {Stage } 4+5} / \mathrm{AEP}_{\text {Stage } 1}\right)}{-t}
$$

where $t$ is the average development time (d) during the main spawning period between stage 1 and stage $4+5$, assuming that eggs are on average halfway through their respective development stage and thus calculated as (Eq. 6):

$$
t=D_{\text {Stage } 5}-\left(D_{\text {Stage } 1 B}+D_{\text {Stage } 5}-D_{\text {Stage } 3}\right) / 2
$$

Coefficients $A$ and $B$ for stage 3 were -0.11 and 2.97, respectively (Thompson \& Riely 1981).

\section{Otolith analysis}

Otoliths from a maximum of 15 ethanol-preserved cod larvae from each station on each date where cod larvae were caught were included in the analysis (161 larvae in total). Each otolith was removed using fine needles under a stereo microscope and deposited in thermoplastic resin on a glass slide. Lapilli were used as a better alternative to the commonly used sagittae because of their more regular pattern of increment deposition and relatively larger size in the early larval stage. There is strong correlation between the width of individual lapilli growth increments and cod larval somatic growth (Bergstad 1984, Dale 1984, Geffen 1995). Both lapilli from each larva were polished with $1 \mu \mathrm{m}$ lapping film. Lapilli $>50 \mu \mathrm{m}$ in diameter were polished on both sides, while smaller otolith were only polished on one side due to high risk of damage or overgrinding. Otolith photos were taken with a Qimaging (FAST 1394) camera mounted on a microscope using $20 \times$ to $63 \times$ magnification objective lenses and analyzed with ImagePro v. 6.3 software. Growth increment width was measured on the longest axis from the core to the edge of each otolith to the nearest $0.15 \mu \mathrm{m}$. Most otoliths did not have a clear hatch mark. Previous studies indicated that hatch marks are located at a radius of approximately 8-13 $\mu \mathrm{m}$ (Bolz \& Lough 1983, Campana 1989, Otterlei et al. 2002). Therefore, it was assumed that the first D-zone (discontinuous zone, dark band within the growth increment) at a minimum distance of $8 \mu \mathrm{m}$ from the central core was the hatch mark ring.

Lapillus growth was expressed as the average width of each growth increment. Curvature at the edge of the lapilli resulted in an underestimation of the width of the outermost 3 growth increments. The 3 outer increments were therefore excluded from further analysis. In the lapillus growth trajectory analysis, only growth increments from a minimum of 3 replicate larvae within each specified group of larvae were included. Recent lapillus growth was calculated as the average increment width of the outermost increment numbers 4,5 and 6 in the 2 lapilli. Only larvae with a minimum of 3 lapillus growth increments were included.

\section{Statistics}

To test for differences in larval growth between areas in the fjord, we analyzed lapillus growth trajectories by a linear mixed model in the R statistical software (R Core Team 2014) using the nlme package (Pinheiro et al. 2014). The model was fitted to the data, where otolith increment width was set as the dependent variable and area as independent. The analysis 
used otolith increment number, area and their interaction as fixed effects. Increment number (grouped by individual otoliths, left and right) were nested by individual larvae and included as a random effect. The random effects were applied to both model intercepts and slopes. As the data contained multiple repeated measurements on otoliths, data were potentially autocorrelated and non-independent (Chambers \& Miller 1995, Campana 1996). To correct for this, the model was refitted with an autocorrelation structure with increment number as a continuous time covariate (grouped for each otolith in each individual larva) using the corCAR1 function (Fox \& Weisberg 2015). Growth increment widths were log transformed. Because the design was unbalanced (i.e. of the 161 larvae analyzed, 30 only had one usable otolith and the number of growth rings differed between otoliths), we used the maximum likelihood to estimate slopes and model significance (Plant 2012).

We next sought to test whether larval growth was affected by environment (water temperature) and prey availability, measured indirectly as in situ prey biomass within the larval prey size spectra, and directly as number of prey items and amount of carbon in a larval gut (as presented in Swalethorp et al. 2014). Estimates of larval growth were based on otolith increment width. We averaged otolith increment widths across the fourth to sixth increments from the otolith edge (approximately days 4 to 6) to link potential growth effects to environmental conditions around the time of capture. As otolith increment width becomes wider with age and older, larger larvae can fit more food in their stomachs simply because of their size, we needed to correct for age effects prior to constructing the models. We explored several methods (linear regression, quadratic regression, kerneldensity regression and Generalized Additive Models [GAMs]) to model mean increment number, as a proxy for age, over approximately days 4 to 6 prior to larval capture against (1) increment width averaged across the fourth to sixth increments closest to the otolith edge, (2) number of prey items in a stomach and (3) amount of prey carbon in a stomach, and ultimately settled on GAMS because these provided the best and smoothest fit. The GAMs used thin plate regression splines to fit the data with a penalized likelihood approach to avoid overfitting. Evaluation of residuals indicated that a Gaussian distribution with an identity link was appropriate to model this data. GAM analyses were carried out using the mgcv package in R (Wood 2006). We used the residuals of these 3 models (henceforth referred to as 'age-corrected' and denoted as age) for further analysis.
To evaluate the effect of temperature, in situ prey biomass, and age-corrected number of prey items and carbon in stomachs on mean, age-corrected otolith increment width across the fourth to sixth increments from the otolith edge, we established a set of 14 candidate linear, additive multiple regression models relating these independent and dependent variables. To provide direct comparison of slopes among the independent variables, all variables were standardized to zero mean and unit variance using the $R$ vegan package (Oksanen et al. 2012). Because samples were collected from 5 locations at 10 time points, it was possible that these random effects could affect the model results. However, comparison of models with and without time and location as random effects (the R package lme4 [Bates et al. 2015] was used to build the mixed models) demonstrated that there was no benefit to including the random effects into the models. Relative model plausibility was evaluated using Akaike's information criteria scores adjusted for small sample size (AICc), and model-averaged slopes and 95\% confidence intervals were calculated from model selection results using the R package AICcmodavg (Mazerolle 2013).

Capture effects where stressed larvae evacuate all food items from their stomachs while in fishing nets have the potential to bias gut content-growth relationships. While there is no perfect way to deal with this largely unknown bias, we conducted analyses first using all larvae and second using only those that had at least one prey item in their gut.

\section{RESULTS}

\section{Hydrography}

The hydrography changed during the study period and differed between stations within the fjord. In March and early April, the water column was completely mixed in the upper $100 \mathrm{~m}$, and this layer was cold, saline and nutrient rich (data not shown, see Riisgaard et al. 2014). By the end of April, warming of the upper $30 \mathrm{~m}$ in the inner half of the fjord branch Kapisigdlit had begun, but no stratification of salinity was apparent (Fig. 2a,b). Temperature increased from the entrance towards the head of the fjord branch. Such a pattern in temperature profiles was apparent at the beginning of June when a thermocline had formed at $20 \mathrm{~m}$ depth. The temperature gradually increased with distance from $4.5^{\circ} \mathrm{C}$ at Stn 1 to $7.8^{\circ} \mathrm{C}$ at Stn 6 (Fig. 2c). During May, melt water from land formed a weak halocline at $20 \mathrm{~m}$ depth 


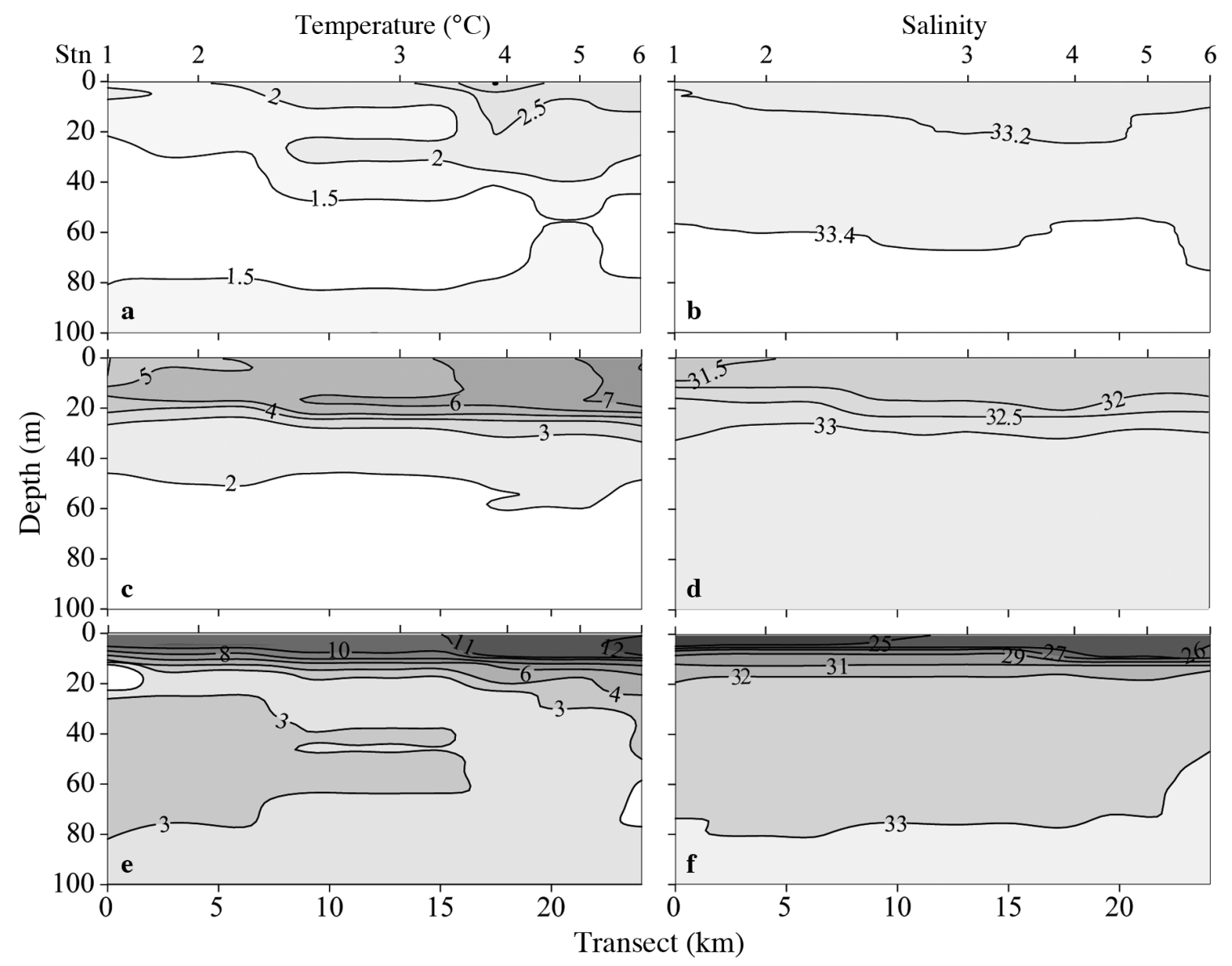

Fig. 2. Vertical sections of temperature $\left({ }^{\circ} \mathrm{C}\right)$ and salinity at the 6 stations along the transect (km). Measured on: (a,b) 30 April, $(\mathrm{c}, \mathrm{d}) 3$ June and $(\mathrm{e}, \mathrm{f}) 6$ July

(Fig. 2d). The halocline strengthened after the breakup of ice around 20 June in Kapisigdlit River, which is located at the head of the fjord branch (Fig. 2f). By early July, temperatures below the pycnocline (10-50 m depth) gradually increased with distance from $2.8^{\circ} \mathrm{C}$ at Stn 1 to $4.4^{\circ} \mathrm{C}$ at $\operatorname{Stn} 6$ (Fig. 2e). At the end of the study period (5 August, data not shown), salinities down to 16 were recorded near the surface. The average temperature below the pycnocline further increased by $0.8^{\circ} \mathrm{C}$ within the inner creek, while it decreased or remained the same at the other stations.

We found an estuarine circulation pattern within Kapisigdlit. Between 17 and 19 June, 3 semi-diurnal tidal cycles were recorded by the acoustic Doppler current profiler measurements at Stn 4. Generally, we found the same flow pattern in the top layer of the water column during all 3 cycles (Fig. 3a). Within the upper $80 \mathrm{~m}$, there was net water outflow (calculated from 2 full semi-diurnal tidal cycles) from Kapisigdlit in the top $30 \mathrm{~m}$ and inflow within the $50 \mathrm{~m}$ layer below (Fig. 3b). There was also evidence of outwardflowing water between 80 and $160 \mathrm{~m}$ and inward flow $>160 \mathrm{~m}$. The outward flow in the top layer likely increased following the ice break-up in Kapisigdlit River. We acknowledge that this study only covered these 3 days of measurements as they represent the conditions during an important phase in the larval life, but flow characteristics would be expected to change during the season.

\section{Atlantic cod distribution}

Cod spawning mainly took place within the inner creek at the head of the fjord. Spawning was initiated between 3 April (Stn 5) and 30 April 30 (Stns 2 and 3) when the average temperature in the upper $30 \mathrm{~m}$ of the water column was between 0.8 and $2.1^{\circ} \mathrm{C}$, respectively. Peak egg abundances were recorded on 10 May within the inner creek, on 24 May at Stn 5 and on 18 May at the 3 outer stations (Fig. 4a), when the average temperature was 3.2 to $4.2^{\circ} \mathrm{C}$ in the upper $30 \mathrm{~m}$. Peak egg abundance within the inner creek (5185 egg $\mathrm{m}^{-2}$ ) was almost 5-6 times higher 


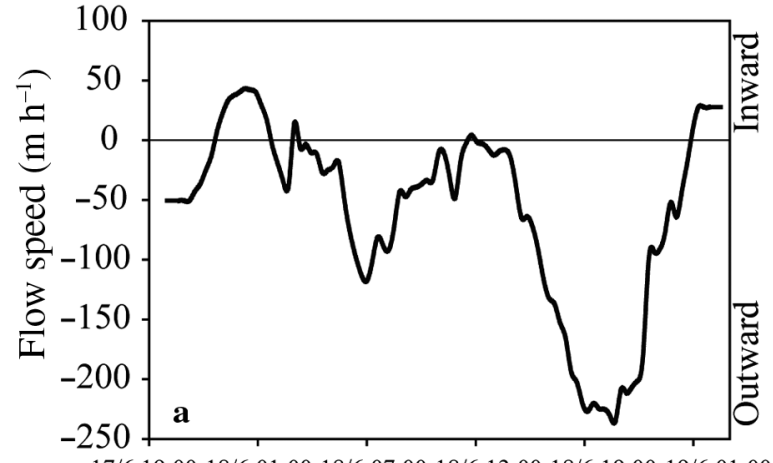

Date \& time

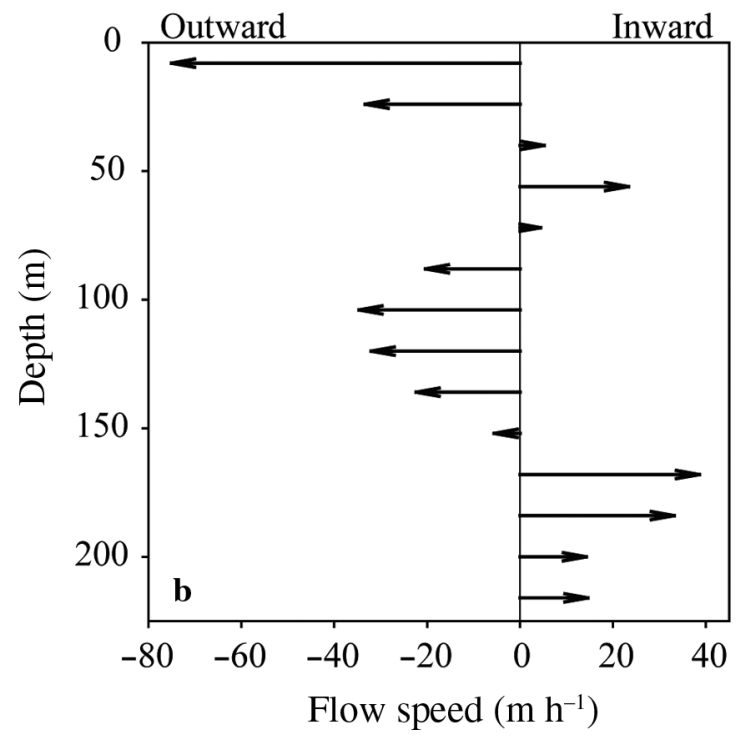

Fig. 3. Water flow inwards and outwards measured at Stn 4 on 17-19 June. (a) Flow $\left(\mathrm{m} \mathrm{h}^{-1}\right)$ averaged in the depth stratum 8-16 $\mathrm{m}$ during 3 tidal cycles; (b) flow $\left(\mathrm{m} \mathrm{h}^{-1}\right)$ averaged within each $16 \mathrm{~m}$ depth stratum during a $24 \mathrm{~h}$ period covering 2 tidal cycles

than at Stn $4\left(893 \mathrm{egg} \mathrm{m}^{-2}\right)$ and Stn $5\left(1079 \mathrm{egg} \mathrm{m}^{-2}\right)$ and around $2-3$ orders of magnitude higher than the outer Stns $2\left(3 \mathrm{egg} \mathrm{m}^{-2}\right)$ and $3\left(103 \mathrm{egg} \mathrm{m}^{-2}\right)$. By 3 June, egg abundances had decreased to less than $5 \%$ of the peak values at all stations, but eggs were found until 18 July in the inner part of Kapisigdlit. Although the inner creek accounted for only a small part of the total study area, it encompassed $71 \%$ of the areal integrated egg abundance (Table 2).

Cod larvae generally hatched within the inner creek and later dispersed out into the fjord. Larvae emerged between 14 April (Stn 5) and 10 May (Stn 2, Fig. 4b). The first larvae were collected 10-16 d after eggs were first found (except for Stn 3 where eggs and larvae emerged at the same time). At Stn 6, peak larval values occurred $24 \mathrm{~d}$ after the highest egg abundances had been recorded, while at Stns 4 and
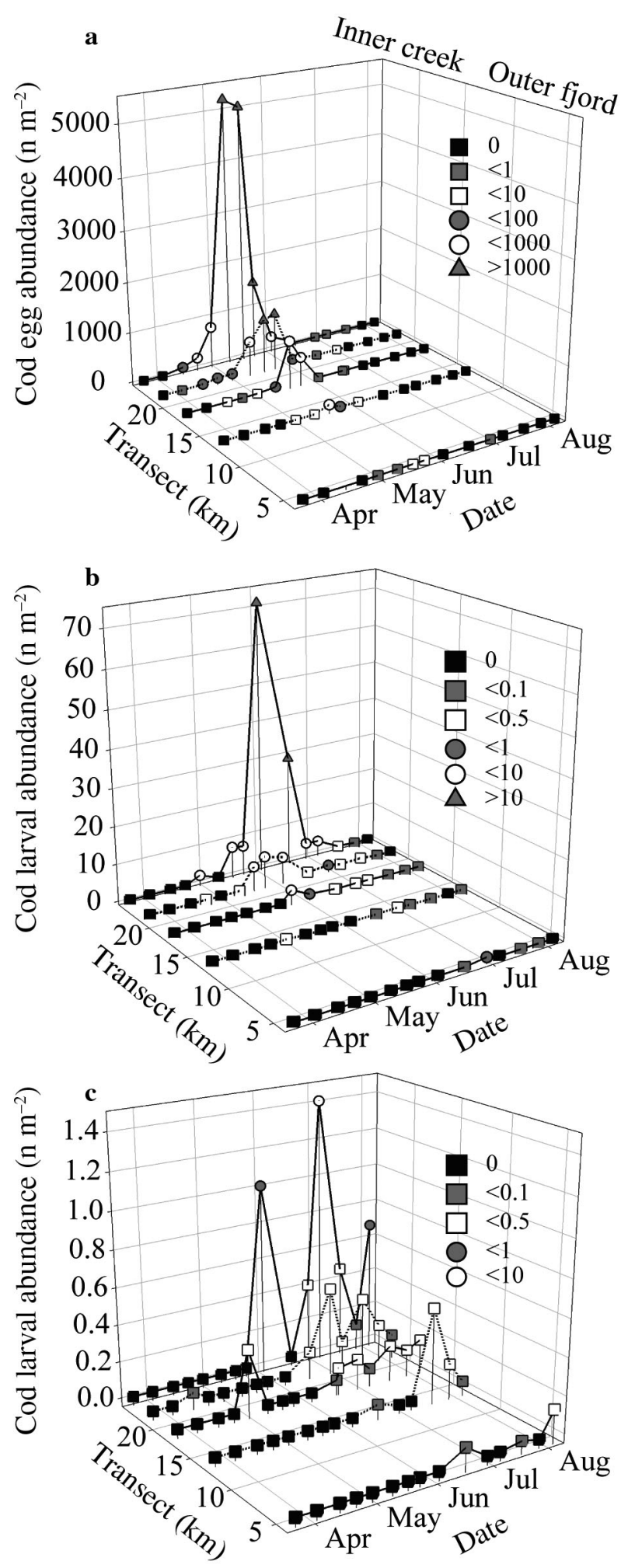

Fig. 4. Abundance of (a) Atlantic cod eggs, (b) larvae $\leq 10$ $\mathrm{mm}$ and (c) larvae $>10 \mathrm{~mm}$ in length at each station and sampling date. Different symbol shapes and shades for each abundance range. Note different scales on $z$ axis 
Table 2. Integrated egg and larval abundance and annual egg production within each area represented by each sampling station. The total number of eggs and larvae collected at each station is shown in brackets. Weighed egg development time from fertilization to hatch (weighed by egg abundance), and average mortality estimates along the fjord transect (between egg stage 1 and $4+5$ ). Development time was calculated from average temperatures within the top $30 \mathrm{~m}$ during the main spawning period (30 April3 June). SL $=$ standard length

\begin{tabular}{|c|c|c|c|c|c|c|}
\hline $\begin{array}{l}\text { Station no.: } \\
\text { Area size }\left(\mathrm{km}^{2}\right) \text { : }\end{array}$ & $\begin{array}{c}2 \\
19\end{array}$ & $\begin{array}{c}3 \\
24.2\end{array}$ & $\begin{array}{c}4 \\
18.6\end{array}$ & $\begin{array}{c}5 \\
8.2\end{array}$ & $\begin{array}{c}6 \\
18.9\end{array}$ & $\begin{array}{l}\text { Fjord } \\
89\end{array}$ \\
\hline $\begin{array}{l}\text { Integrated egg abundance } \\
\left(\mathrm{n} \text { area }^{-1}\right)\end{array}$ & $\begin{array}{c}1.07 \times 10^{9} \\
(<1 \%, \mathrm{n}=467)\end{array}$ & $\begin{array}{c}2.43 \times 10^{10} \\
(2 \%, \mathrm{n}=1480)\end{array}$ & $\begin{array}{c}2.01 \times 10^{11} \\
(14 \%, \mathrm{n}=5024)\end{array}$ & $\begin{array}{c}1.90 \times 10^{11} \\
(13 \%, \mathrm{n}=13503)\end{array}$ & $\begin{array}{c}1.02 \times 10^{12} \\
(71 \%, \mathrm{n}=41169)\end{array}$ & $1.43 \times 10^{12}$ \\
\hline Egg development time $(\mathrm{d})$ & & & & & & 21.4 \\
\hline Egg mortality (\%) & & & & & & 90.3 \\
\hline Egg daily mortality & & & & & & 0.158 \\
\hline $\begin{array}{l}\text { Integrated larval abundance } \\
\left(\mathrm{n} \mathrm{area}^{-1}\right)\end{array}$ & $\begin{array}{l}2.26 \times 10^{8} \\
(\mathrm{n}=18)\end{array}$ & $\begin{array}{l}3.55 \times 10^{8} \\
(\mathrm{n}=29)\end{array}$ & $\begin{array}{l}6.74 \times 10^{8} \\
(\mathrm{n}=98)\end{array}$ & $\begin{array}{l}1.75 \times 10^{9} \\
(\mathrm{n}=277)\end{array}$ & $\begin{array}{l}1.46 \times 10^{10} \\
(\mathrm{n}=858)\end{array}$ & $1.76 \times 10^{10}$ \\
\hline \multicolumn{7}{|c|}{ Relative larval abundance at station } \\
\hline$\leq 10 \mathrm{~mm} \mathrm{SL}$ & $1 \%$ & $1 \%$ & $5 \%$ & $12 \%$ & $81 \%$ & \\
\hline$>10 \mathrm{~mm} \mathrm{SL}$ & $3 \%$ & $21 \%$ & $20 \%$ & $12 \%$ & $44 \%$ & \\
\hline $\begin{array}{l}\text { Annual egg production } \\
\left(\mathrm{n} \mathrm{m}^{-2}\right)\end{array}$ & 10 & 105 & 949 & 2202 & 14181 & \\
\hline $\begin{array}{l}\text { Annual egg production } \\
\left(\mathrm{n} \text { area }^{-1}\right)\end{array}$ & $\begin{array}{l}1.91 \times 10^{8} \\
(<1 \%)\end{array}$ & $\begin{array}{l}2.53 \times 10^{9} \\
(1 \%)\end{array}$ & $\begin{array}{c}1.76 \times 10^{10} \\
(10 \%)\end{array}$ & $\begin{array}{c}1.81 \times 10^{10} \\
(10 \%)\end{array}$ & $\begin{array}{c}1.35 \times 10^{11} \\
(78 \%)\end{array}$ & $1.73 \times 10^{11}$ \\
\hline
\end{tabular}

5, eggs and larvae peaked around the same time. Peak larval abundance within the inner creek (72 larvae $\mathrm{m}^{-2}$ ) was almost 10 and 50 times higher compared with Stns 5 ( 7.7 larvae $\mathrm{m}^{-2}$ ) and 4 (1.5 larvae $\left.\mathrm{m}^{-2}\right)$, respectively, and 2 orders of magnitude higher than the outer Stns $2\left(0.8\right.$ larvae $\left.\mathrm{m}^{-2}\right)$ and $3(0.5$ larvae $\mathrm{m}^{-2}$ ). While the smaller, younger larvae ( $\leq 10 \mathrm{~mm}$ length) were more concentrated at Stn 6, the larger, older larvae $(>10 \mathrm{~mm}$ ) were more evenly distributed along the fjord transect (Fig. $4 \mathrm{~b}, \mathrm{c}$ ). When comparing the 5 areas, $83 \%$ of the integrated larval abundance was located within the inner creek (Table 2). For the smaller larvae, $81 \%$ were located in the inner creek compared with only $44 \%$ of the larger larvae.

The vertical distribution of cod eggs in the inner creek during the period between peak occurrence of eggs and larvae showed that $95 \%$ of the cod eggs were located in the upper $30 \mathrm{~m}$ of the water column (Fig. 5). Decreasing water salinity in the upper $20 \mathrm{~m}$ resulted in a higher fraction of the neutrally buoyant cod eggs sinking below the pycnocline (Fig. 5b,c). A few larvae were also caught on 24 May (2.5 larvae $\mathrm{m}^{-3}$ ) and 3 June (3.3 larvae $\left.\mathrm{m}^{-3}\right)$ in the $10-20 \mathrm{~m}$ and 20-30 m depth layers, respectively (data not shown).

\section{Cod egg development and mortality}

We found an overall daily egg mortality of $16 \%$ along the transect in Kapisigdlit (Table 2). It was assumed that the disappearance of eggs between development stages 1 to $4+5$ was due to mortality. During the main spawning period, the average percentage of eggs in developmental stages $4+5$ was 6 , 4 and $14 \%$ in the outer fjord (Stns 2, 3 and 4), slope (Stn 5) and inner creek (Stn 6), respectively. At the inner creek, stage 4 and 5 eggs were only found in the top $30 \mathrm{~m}$ of the water column, and these first occurred on 10 May, $26 \mathrm{~d}$ after the first occurrence of stage 1 eggs.

\section{Areal production}

The average daily egg production within the inner creek was 134 eggs $\mathrm{m}^{-2}$ (maximum 685 eggs $\mathrm{m}^{-2}$ measured on 10 May) and substantially higher than the fjord average of 18 eggs $\mathrm{m}^{-2}$ (maximum 162 eggs $\mathrm{m}^{-2}$ measured on 10 May). The inner creek area contributed most of the AEP within Kapisigdlit (Table 2). The AEP for the entire Kapisigdlit fjord branch corresponded to 212000 spawning females and a spawing stock biomass (SSB) of 1090 tons.

\section{Cod larval growth}

There was a strong relationship between larval length and otolith size (Fig. S1a in the Supplement at www.int-res.com/articles/suppl/m555p185_supp.pdf). Linear mixed models demonstrated that larval otolith growth trajectories differed throughout the fjord. 


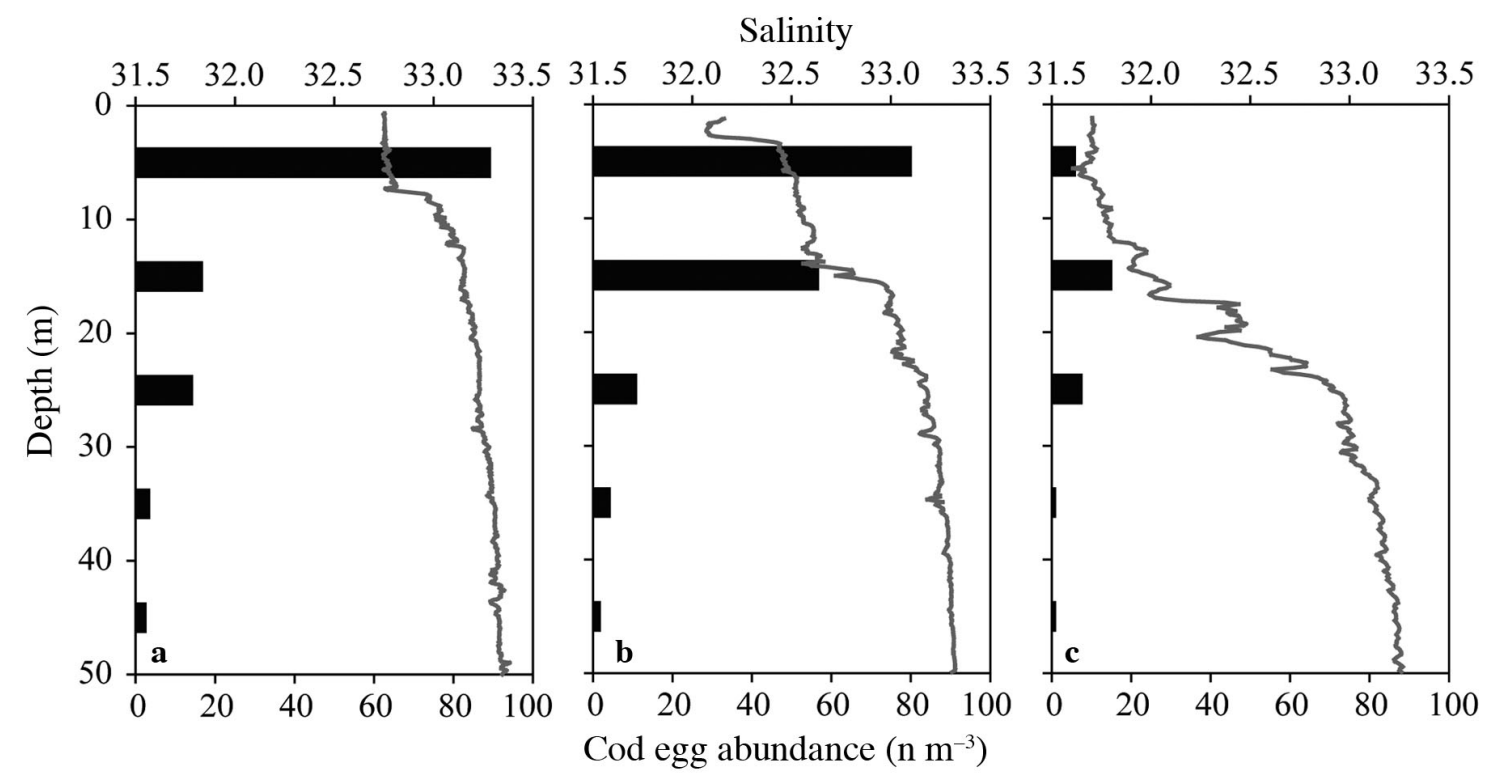

Fig. 5. Atlantic cod egg abundance (bars) within five 10-m depth strata on (a) 10 May, (b) 24 May and (c) 3 June at Stn 6 . Gray lines illustrate water salinity profile at each sampling date

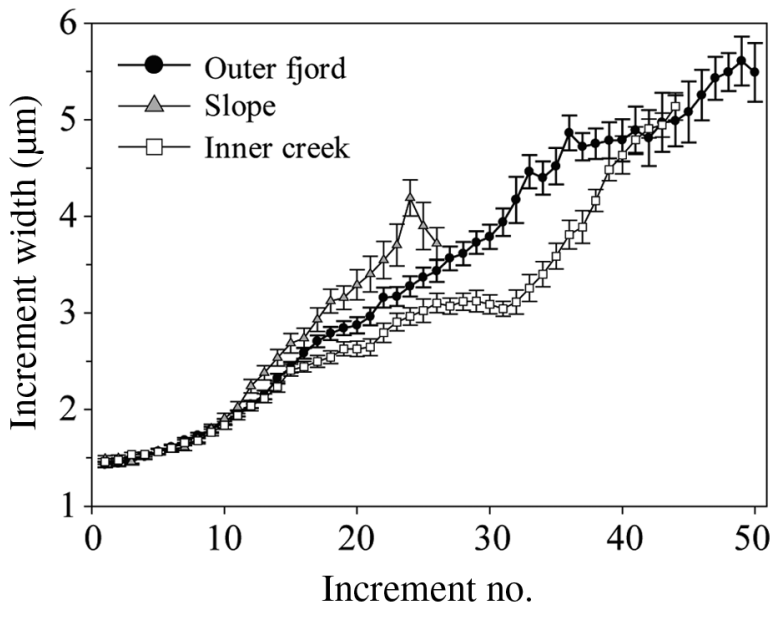

Fig. 6. Average growth increment width $( \pm \mathrm{SE})$ per lapillus increment number in the outer fjord (Stns 2, 3 and 4), on the slope (Stn 5) and within the inner creek (Stn 6). Due to low numbers of larvae caught early in the season, larvae from Stns 2, 3 and 4 were pooled

Larvae located within the inner creek (Stn 6) grew slower than larvae on the slope (Stn 5) and outer fjord (Stns 4, 3 and 2, Fig. 6). This spatial difference in growth increment width was clear between increments $12-16$ and 38 . The interaction between geographical area and otolith growth increment number for the inner creek differed significantly from the slope and outer fjord, respectively ( $\mathrm{df}=4274, t=$ $2.371, \mathrm{p}=0.018$, and $\mathrm{df}=4274, t=2.635, \mathrm{p}=0.008$, respectively). There was no significant difference between the slope and outer fjord ( $\mathrm{df}=4274, t=$ $-0.349, \mathrm{p}=0.727$ ).

The GAMs revealed positive relationships between mean increment number, as a proxy for age, and mean otolith increment width across the fourth to sixth increments closest to the otolith edge (Fig. $7 \mathrm{a}, \mathrm{r}^{2}=0.82, \mathrm{p}<0.00001$, optimal number of knots $\left(k^{\prime}\right)=9$ ), number of prey items in a larval gut (Fig. $7 \mathrm{~b}, \mathrm{r}^{2}=0.37, \mathrm{p}<0.00001, \mathrm{k}^{\prime}=9$ ), and amount of prey carbon in a larval gut (Fig. $7 \mathrm{c}, \mathrm{r}^{2}=0.58$, p < $0.00001, k^{\prime}=9$ ). Using residuals of these models, model selection demonstrated a strong, positive effect of age-corrected ( age) number of prey items in larval stomachs and growth during approximately days 4 to 6 prior to capture (Table 3). All of the top models included age-corrected number of prey items in stomachs, and the univariate model that included this variable alone explained $26 \%$ of the variation in otolith increment width and was indistinguishable from the most plausible model that also included age-corrected prey carbon in stomachs (Table 3, Fig. 8a). Model-averaged slopes indicated that age-corrected number of prey items in larval stomachs was the only independent variable that did not have $95 \%$ confidence intervals overlap with 0 (Table 4). There was not a strong indication that age-corrected otolith increment width was affected by temperature, in situ prey biomass or agecorrected stomach carbon, although 
the univariate model that included stomach carbon and temperature explained $8 \%$ of the variance in age-corrected otolith increment width and had a pvalue of 0.03 (Table 3, Fig. 8b-d). Qualitatively there was no difference in the results when including $(n=153)$ or excluding $(n=117)$ larvae with empty stomachs (Tables $3 \& 4$, and Tables S1 \& S2 in the Supplement).
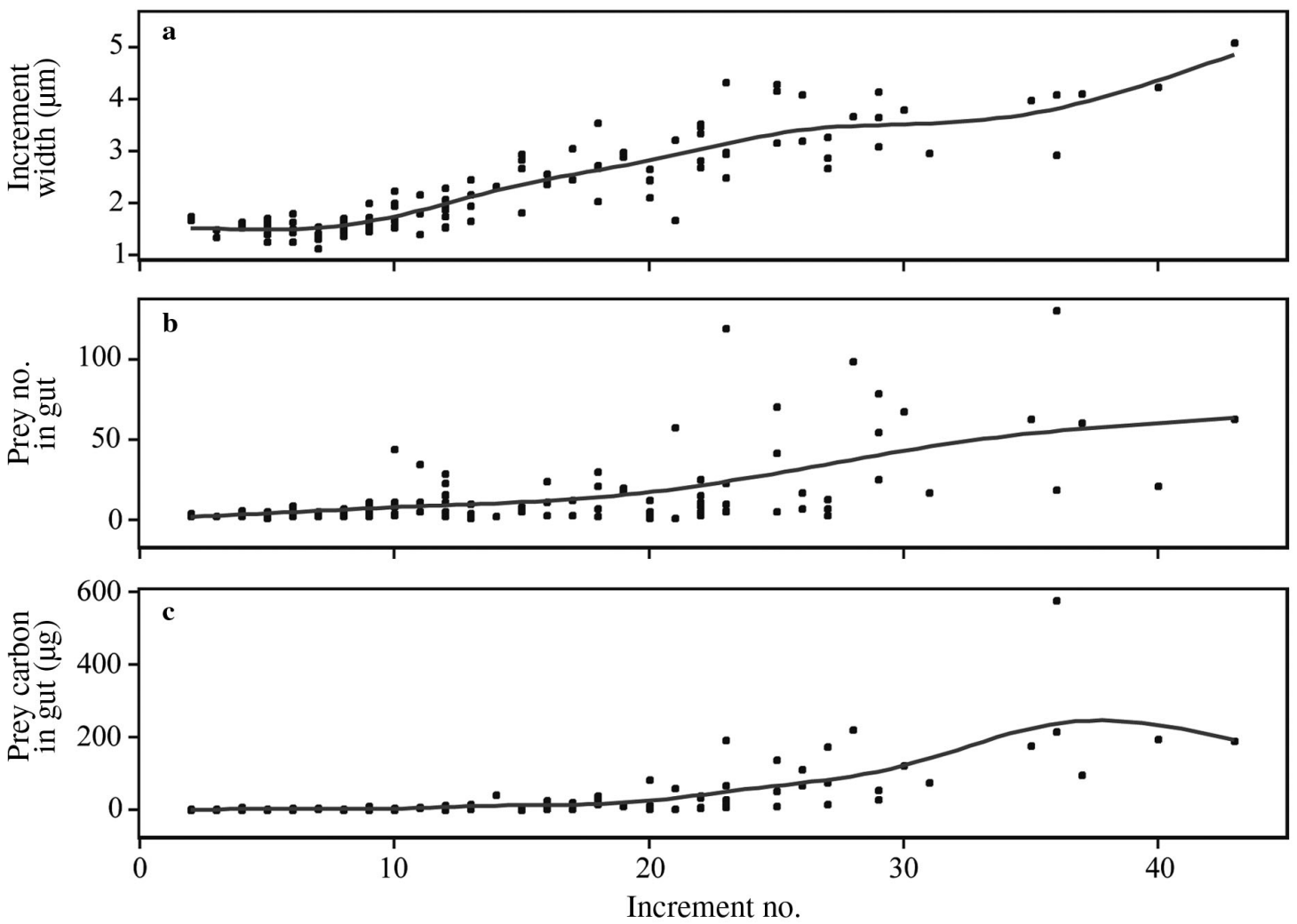

Fig. 7. Relationship between larval otolith growth increment number, as a proxy for age, and (a) mean width of increments 4 to 6 from the otolith edge, (b) number of prey items in a larval gut, and (c) amount of carbon in a larval gut. Curves are best fit estimates based on the Generalized Additive Model. This analysis included only larvae with at least one prey item in its gut

Table 3. Results of multiple regression models correlating residuals of otolith increment width age, using otolith increment number as a proxy for age, against: residuals of prey carbon in a larval gut age; residuals of prey number in a larval gut age; in situ prey biomass from Swalethorp et al. (2014); and ocean temperature. $\mathrm{K}$ is the number of parameters and $\Delta \mathrm{AICc}$ is the difference between a given model and the most plausible model, model weight is the weight of a given model, and cumulative weight is the weight of a given model plus all of the more plausible models. Only models within 10 AICc of the most plausible are shown. Only larvae with prey in their stomachs were used for this analysis. Results using all larvae are in the Supplement at www.int-res.com/articles/suppl/m555p185_supp.pdf

\begin{tabular}{|c|c|c|c|c|c|c|c|}
\hline Independent variables correlated against otolith increment width age & $\mathrm{K}$ & $\mathrm{AICC}$ & $\triangle \mathrm{AICc}$ & $\begin{array}{l}\text { Model } \\
\text { weight }\end{array}$ & $\begin{array}{l}\text { Cumul. } \\
\text { weight }\end{array}$ & $\underset{\mathrm{R}^{2}}{\text { Multiple }}$ & $\mathrm{p}$ \\
\hline Prey carbon in gut age + prey no. in gut age & 4 & 253.48 & 0 & 0.27 & 0.27 & $0.28<-$ & $<0.0001$ \\
\hline Prey no. in gut age & 3 & 253.6 & 0.12 & 0.25 & 0.52 & $0.26<$ & $<0.0001$ \\
\hline Prey no. in gut age + in situ prey biomass & 4 & 254.96 & 1.48 & 0.13 & 0.65 & $0.27<$ & $<0.0001$ \\
\hline Prey carbon in gut age + prey no. in gut age + in situ prey biomass & 5 & 255.06 & 1.58 & 0.12 & 0.78 & $0.28<$ & $<0.0001$ \\
\hline Prey no. in gut age + temperature & 4 & 255.27 & 1.78 & 0.11 & 0.89 & $0.26<$ & $<0.0001$ \\
\hline Prey no. in gut age + in situ prey biomass + temperature & 5 & 256.26 & 2.78 & 0.07 & 0.95 & 0.27 & $<0.0001$ \\
\hline $\begin{array}{l}\text { Prey carbon in gut } \sim \text { age }+ \text { prey no. in gut } \sim \text { age }+ \text { in situ prey biomass } \\
+ \text { temperature }\end{array}$ & 6 & 256.98 & 3.5 & 0.05 & 1 & 0.29 & $<0.0001$ \\
\hline
\end{tabular}



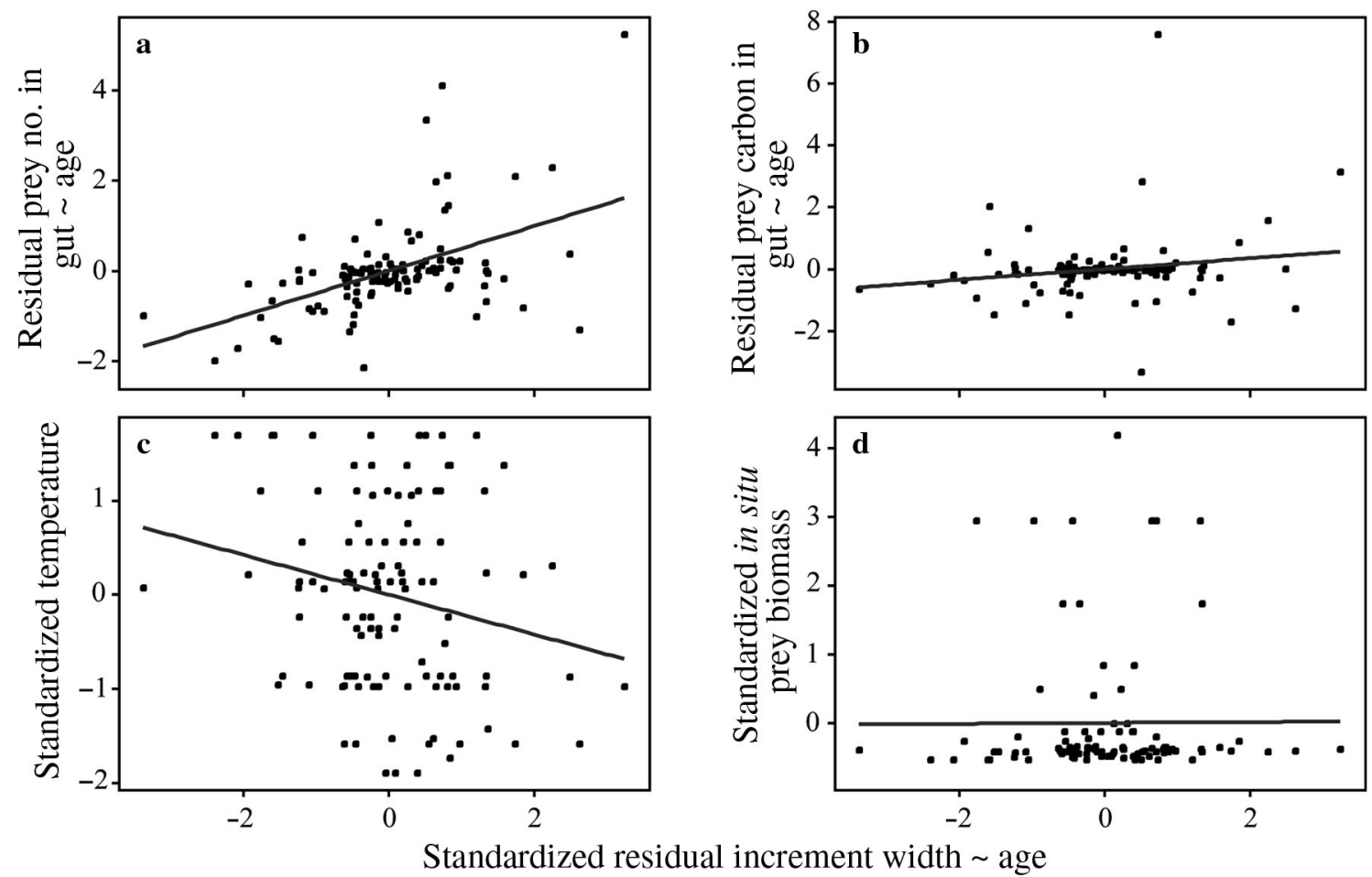

Fig. 8. Univariate relationships between residuals of Generalized Additive Models of mean otolith growth increment width age (dependent variable), using otolith increment number, as a proxy for age, versus (a) residuals of number of prey items in a larval gut age, (b) residuals of amount of prey carbon in a larval gut age, (c) temperature and (d) in situ prey biomass. All variables were standardized to zero mean and unit variance

Table 4. Model-averaged estimates of the slopes $(\beta)$ and $95 \%$ confidence limits (CL) of independent variables used in model-selection analysis

\begin{tabular}{|lrrc|}
\hline Variable & $\beta$ & $\begin{array}{c}\text { Lower 95\% } \\
\text { CL }\end{array}$ & $\begin{array}{c}\text { Upper 95\% } \\
\text { CL }\end{array}$ \\
\hline Stomach prey carbon & -0.15 & -0.35 & 0.05 \\
Stomach prey no. & 0.52 & 0.32 & 0.73 \\
In situ prey biomass & 0.09 & -0.10 & 0.27 \\
Temperature & -0.07 & -0.25 & 0.11 \\
\hline
\end{tabular}

\section{DISCUSSION}

\section{Cod spawning}

Our results show that spawning of local fjord populations of cod can be strongly restricted, both spatially and temporally. In the population considered, a shallow, inshore locality was shown to be the important spawning ground, in agreement with past studies (Jensen \& Hansen 1931, Hansen 1949, Smidt 1979). Accordingly, increasing egg densities towards the head of fjords has also been documented for cod populations in Canada and Norway (Knutsen et al.
2007, Knickle \& Rose 2010). The timing of spawning in Atlantic cod has been shown to be closely related to water temperature (Kjesbu 1994). In our study, temperature increased from the mouth of Kapisigdlit to the inner creek, where spawning occurred earlier. Spawning was concentrated within $1 \mathrm{mo}$, but extended over 3.5 mo. Such prolonged spawning may be the result of adults being subjected to different thermal regimes (Knickle \& Rose 2010) while migrating from different parts of the fjord (e.g. residing at greater depth for longer or shorter periods of time).

The average daily egg production at the principal spawning site at the head of the fjord was higher than those reported from high productive areas in the North Sea (up to 33 eggs $\mathrm{m}^{-2}$, Fox et al. 2008), while the average daily egg production for the entire fjord was in the lower end of those reported from Georges Bank (up to 48 eggs $\mathrm{m}^{-2}$, Mountain et al. 2008). Smidt (1979) found that egg abundance in Kapisigdlit fjord was even higher at a sampling station located further inside the shallow creek than our Stn 6, while his Stns 5 and 6 were comparable to our study. Because spawning cod are readily caught within the entire inner creek (R. Hedeholm pers. 
comm.), it is likely that spawning occurs throughout the entire creek area. However, due to low numbers of eggs collected at the outer stations and a general lack of variance estimates, egg abundance and AEP should be interpreted with some caution.

The Godthåbsfjord system covers $2161 \mathrm{~km}^{2}$. Considering that cod eggs and larvae are also found in other fjord branches (Smidt 1979, Engelstoft 1997, Storr-Paulsen et al. 2004, Swalethorp et al. 2015, P. Munk unpubl. data), and that there is no genetic differentiation between cod from these branches (Therkildsen et al. 2013), the estimated AEP and SSB would be a minimum estimate for the Godthåbsfjord system. The peak egg abundances within Kapisigdlit suggest that AEP and SSB were high compared with fjords in other areas, as egg abundances have not been reported higher than $36-536$ eggs $\mathrm{m}^{-2}$ in 21 Norwegian fjords (Espeland et al. 2007, Knutsen et al. 2007) or 46 eggs $\mathrm{m}^{-2}$ from Smith Sound, Canada (Knickle \& Rose 2010). Furthermore, our assumption of no egg mortality during the first development stage should make the AEP and SSB conservative estimates.

\section{Egg and larval dispersal}

Distributions of eggs and larvae changed markedly over the course of the study, likely driven by changes in water column structure and circulation. Initially, cod eggs and young larvae were mainly found within the inner part of the fjord, despite the presence of outward flow in the upper water column. Hansen (1949) and Smidt (1979) suggested that eggs and larvae are rapidly dispersed by currents, as they recorded large differences between egg and larvae caught within Kapisigdlit and outside the fjord branch. We measured a current of $1.8 \mathrm{~km}$ residual flow per day in the top layer at Stn 4 before the ice break-up in Kapisigdlit River. Therefore, during the main spawning season (30 April-3 June), eggs spawned within the inner creek could have drifted up to $40 \mathrm{~km}$ out before hatching. However, we found that the dispersal of eggs and young larvae was limited early in the season. The outward flow in the surface layer could be lower at the shallow inner Stn 6 compared with the centrally located Stn 4 , and may on average be lower than what we measured over just 2 tidal cycles. Furthermore, a large proportion of the eggs were located below the top layer where the outward current was weaker. Rotational dynamics in water circulation that at high latitudes can exist in narrow fjords (Asplin et al. 1999, Cottier et al. 2010) could also have reduced egg and larval dispersal within Kapisigdlit. Changes in wind direction (Asplin et al. 1999), tidal advection (Fortier \& Leggett 1982), and timing and magnitude of freshwater input (Myksvoll et al. 2011, 2014) can also greatly affect dispersal.

Later in the season, we observed that especially larger larvae were more evenly distributed along the fjord transect (also see Swalethorp et al. 2014). This shift in distribution was seen after the ice broke in Kapisigdlit River, which significantly increased the freshwater outflow to the fjord. Myksvoll et al. (2011) defined a 'window of leakage' that occurs right at the start of melt water input and onset of estuarine circulation. This window lasts for approximately $1 \mathrm{mo}$, and transports low-density eggs residing in the top layer outward. Wind-driven currents can also disperse buoyant eggs before the water column becomes stratified, displacing the eggs to the deeper mixed layer (Knickle \& Rose 2010) while trapping the wind-driven current near the surface layer (Svendsen \& Thompson 1978). A 'window of leakage' seemed apparent in our study. The ice in Kapisigdlit River broke around 20 June, when $91 \%$ of the larvae had already hatched. After the ice break-up, larvae started drifting out as $81 \%$ of the $\leq 10-\mathrm{mm}$-long larvae were located within the inner creek area, compared with only $44 \%$ of the $>10$-mm-long larvae. Moreover, the peak in larval abundance at the outer stations (Stns 2 and 3) occurred very late in the season, $3 \mathrm{wk}$ later than stage $4+5$ eggs. Thus, cod larvae found at the 2 outer stations probably originated from the inner creek. The 'window of leakage' closes when a strong pycnocline is established (Myksvoll et al. 2011). At this time, many larvae were actively swimming and feeding around the top layer. Herring larvae have been found to actively modify their dispersal by migrating upward and crossing the pycnocline during tidal flooding (Fortier \& Leggett 1982, 1983). Cod drift trajectories can also differ for larvae inhabiting different depths (Vikebø et al. 2005), and larvae have been found to aggregate close to or within the stratified layer (Lough \& Potter 1993), performing vertical migrations and crossing strong haloclines (Grønkjær \& Wieland 1997). Because currents within or just below the pycnocline may move in the same direction as the surface layer (Wiseman \& Garvine 1995), cod larvae residing there were potentially dispersed out.

\section{Egg mortality}

The observed restriction of spawning to the innermost part of Kapisigdlit may have facilitated egg sur- 
vival. Overall, our daily egg mortality estimate from the fjord was within the lower range of $10-32 \%$ daily mortality reported in other cod spawning areas (Campana et al. 1989, Köster \& Möllmann 2000, Wieland et al. 2000, Armstrong et al. 2001, Mountain et al. 2003, Mountain et al. 2008). This low mortality might be due to sheltered conditions and specific hydrographical settings, such as temperature, occurring in such inshore areas (Wroblewski et al. 2005, Knutsen et al. 2007). The temperature was highest within the inner creek and could have reduced the development time by as much as $1.5 \mathrm{~d}$ compared with the outermost station (Stn 2) during the main spawning period (30 April-3 June). This would have left the passively drifting eggs less exposed to predation. The scarcity of potential egg predators within the main spawning area may also explain the lower mortality. Large krill $(>2.5 \mathrm{~cm})$ were abundant in the outer fjord (Agersted \& Nielsen 2014), but only a few were caught on the slope or within the inner creek. Krill may be capable of consuming fish eggs considering they have been shown to consume large copepods (Falk-Petersen et al. 2000, Torgersen 2001) and northern anchovy larvae (Theilacker \& Lasker 1974). Moreover, chaetognaths are voracious planktonic predators that eat early life stages of fish (Frank \& Leggett 1985, and references therein) and their abundances were twice as high on the slope and in the outer fjord compared with the inner creek. Hence, the relatively lower abundances of potential predators around the main spawning site may have contributed to the low daily mortality.

\section{Growth}

Atlantic cod larval otoliths showed significant differences in growth trajectories in different areas of the fjord. These results are similar to those reported by Landaeta \& Castro (2006) in Chile, where larger larval rockfish dispersed out from the inner fjords and attained faster growth. Interestingly, food, rather than temperature, appeared to be the main driver of growth in Kapisigdlit. Many studies have shown that larval fish growth is highly temperature dependent (Otterlei et al. 1999, Steinarsson \& Björnsson 1999, Otterlei et al. 2002). The average temperature (top $30 \mathrm{~m}$ ) was $0.8-2.4^{\circ} \mathrm{C}$ higher within the inner creek, so it is somewhat surprising that there was no correlation between temperature and growth. The background could be density dependence due to an increased competition for food within the inner creek area (Byström \& Garcia-Berthou 1999, Swalethorp et al. 2014). The size composition and the potential nutritional quality of the prey differed considerably between the areas (Swalethorp et al. 2014). Although we did not find a direct relationship between growth and in situ prey biomass, there was a positive correlation between the amount of food in a larvae's stomach and growth. A possible reason for the lack of a relationship between in situ prey biomass and recent growth was the temporal mismatch between the 2 estimates, since larvae growth was estimated $\geq 4-6 \mathrm{~d}$ earlier than the in situ prey biomass and during which time the larvae could also have drifted from one area to another. Furthermore, larval prey perception is also affected by light (Huse 1994) and small-scale turbulence affects the prey encounter rate (MacKenzie \& Kiørboe 2000). Although light intensities were always above $3.67 \times 10^{-6} \mathrm{~W} \mathrm{~m}^{-2}$ in the top $50 \mathrm{~m}$ of the water column, at which cod larvae are capable of feeding (Vollset et al. 2011), and gut content was not affected by time of day (Swalethorp et al. 2014), small-scale turbulence generated by e.g. tidal flow and wind is likely to have differed both spatially and temporally.

We used ring increment number as a proxy for age, but patterns in increment width indicate that larvae did not deposit daily growth increments during the first part of their life. Compared with cod larvae from the Grand Banks and North Sea (Campana 1996, Nielsen \& Munk 2004), lapillus increment widths were $\sim 50 \%$ wider for the first 10 growth increments and became twice as wide thereafter. Although lapillus growth rates were comparable to some other studies (Suthers \& Sundby 1993, Otterlei et al. 2002, Van der Meeren \& Moksness 2003), comparison of length at increment number (age) with literature values also suggested that up until the size of metamorphosis ( 12 mm length) growth increments in our study may only have been distinguished for approximately every second day (Fig. S1b, Bolz \& Lough 1983, 1988, Campana \& Hurley 1989, Meekan \& Fortier 1996, Green et al. 2004, Nielsen \& Munk 2004). Indistinguishable ring patterns are seen for larvae inhabiting temperatures of $6^{\circ} \mathrm{C}$ or less (Otterlei et al. 2002), a thermal regime that the present larvae experienced during their early life. However, considering that most young cod were located in the inner creek area, it is reasonable to assume that these were all subjected to the same environmental conditions during the early life and deposited otolith growth increments in a similar way, thus allowing us to ascertain relative differences and carrying out inter-regional comparisons using a linear mixed model. This model is ideal since it can deal with unbalanced datasets such as 
most datasets of otolith growth trajectories from multiple field caught fish (i.e. different number of readable otoliths within larvae and number of increments within otoliths). Repeated measurements ANOVA, which is frequently used for this type of analysis, is not able to handle unbalanced datasets and consequently most data points have to be omitted when using this analysis. Lastly, when only part of the growth or feeding history is to be considered, GAMs are more appropriate than linear models as they do not assume linearity, but are adaptable to temporal changes in the relationships e.g. changes in the rate of readable otolith growth increment deposition.

\section{CONCLUSIONS AND PERSPECTIVE}

Our work on the early life history of a historically successful inshore population of Atlantic cod identified key features governing the success in early life and likely larval recruitment to the population. Spawning mainly occurred within a shallow and sheltered area at the head of the fjord. Initially, eggs and young larvae remained concentrated within this shallow area despite the presence of a moderate outflow of water in the surface layer. Egg daily mortality was low in the fjord, possibly due to the sheltered nature of the spawning area where temperatures were relatively high and abundances of potential predators low. Later in the season, most of the older actively feeding larvae had been transported into the main part of the Kapisigdlit fjord. This was observed after the seasonal peak in river runoff, which may have facilitated the larval dispersal, as has been demonstrated in other fjords (Myksvoll et al. 2011, 2014). Larval otolith growth trajectories showed that larvae that were transported into the main fjord, where prey availability was higher (Swalethorp et al. 2014), had a significantly faster growth rate, and that gut content rather than temperature influenced attainable growth rates. That fish spawn upstream from nursery grounds is well documented in oceanic migratory cod (Bergstad et al. 1987) reflecting an adaptive use of ocean hydrodynamics (Knutsen et al. 2007). Our study indicated an adaptive use of water flow in fjord populations, while timing between spawning and freshwater inflow may have been essential for retention of passive early stages and dispersal of older, actively feeding larvae, patterns which ultimately could determine survival chances.

Our results underscore the importance of phenology to survival chances of early life stages of Atlantic cod. Recent research on marine fish phenology suggests that the timing of spawning correlates with water temperature (Greve et al. 2005, Genner et al. 2010, Poloczanska et al. 2013) and that spawning has progressively arrived earlier in the year for many fishes over the past 60 yr (Asch 2015). Moreover, change in fish phenology does not necessarily correlate with phenology of the prey (e.g. zooplankton), thus potentially decoupling larval fish from their food source (Asch 2015). Chances of survival for eggs and larvae may thus change with potential future changes in freshwater outflow (see Myksvoll et al. 2011, 2014), changes in temperature or wind conditions, or changes in food resources.

The relatively high AEP and SSB estimated for the population in this fjord branch underline the significance of local populations, considering that over half of the known North Atlantic spawning groups of cod are such sedentary fjord populations (Robichaud \& Rose 2004). Their importance to local communities, their potential role in rebuilding the offshore stocks (Wroblewski et al. 2005) and their genetic distinctness on small geographic scales (Jorde et al. 2007) calls for further investigations to enable fishery management on an individual population level.

Acknowledgements. This research project was funded by the Greenland Climate Research Centre (project 6505). We thank the captains and crew on 'Lille Masik' and RV 'Dana' for their help during sampling. We also thank Sanne Kjellerup, Karen Riisgaard, Sara Zamora Terol, Birgit Søborg, Thomas Krog, Knud Kreutzmann, Henrik Philipsen and John Mortensen for help with logistics, equipment and sampling. Furthermore, we thank Karin Hüssy and Arild Folkvord for their support concerning the otolith analysis. In addition, we thank Pierre Pepin, Geoff Evans and Jan Heuschele for statistical support, Kerstin Geitner for graphical support, and William Watson and Julie Dinasquet for providing comments on the manuscript.

\section{LITERATURE CITED}

Agersted MD, Nielsen TG (2014) Krill diversity and population structure along the sub-Arctic Godthåbsfjord, SW Greenland. J Plankton Res 36:800-815

Armstrong MJ, Connolly P, Nash RDM, Pawson MG and others (2001) An application of the annual egg production method to estimate the spawning biomass of cod (Gadus morhua L.), plaice (Pleuronectes platessa L.) and sole (Solea solea L.) in the Irish Sea. ICES J Mar Sci 58: 183-203

Asch RG (2015) Climate change and decadal shifts in the phenology of larval fishes in the California Current ecosystem. Proc Natl Acad Sci USA 112:E4065-E4074

Asplin L, Salvanes AGV, Kristoffersen JB (1999) Nonlocal wind-driven fjord-coast advection and its potential effect on plankton and fish recruitment. Fish Oceanogr 8: 255-263 
Bates D, Maechler M, Bolker B, Walker S (2015) lme4: linear mixed-effects models using Eigen and S4 R package version 1.1-10. http://CRAN.R-project.org/package=lme4

Bergstad A (1984) A relationship between the number of growth increments on the otoliths and age of larvae and juvenile cod, Gadus morhua. In: Dahl E, Danielssen DS, Moksness E, Solemdal P (eds) The propagation of cod Gadus morhua L. Flødevigen Rapportser, Part 1. Institute of Marine Research, Arendal, p 251-272

Bergstad OA, Jørgensen T, Dragesund O (1987) Life history and ecology of the gadoid resources of the Barents Sea. Fish Res 5:119-161

Bolz GR, Lough RG (1983) Growth of larval Atlantic cod, Gadus morhua, and haddock, Melanogrammus aeglefinus, on Georges Bank, spring 1981. Fish Bull 81:827-836

Bolz GR, Lough RG (1988) Growth through the 1st 6 months of Atlantic cod, Gadus morhua, and haddock, Melanogrammus aeglefinus, based on daily otolith increments. Fish Bull 86:223-235

Bonanomi S, Pellissier L, Therkildsen NO, Hedeholm RB and others (2015) Archived DNA reveals fisheries and climate induced collapse of a major fishery. Sci Rep 5: 15395

Bradbury IR, Laurel BJ, Robichaud D, Rose GA and others (2008) Discrete spatial dynamics in a marine broadcast spawner: re-evaluating scales of connectivity and habitat associations in Atlantic cod (Gadus morhua L.) in coastal Newfoundland. Fish Res 91:299-309

Buch E, Horsted SA, Hovgard H (1994) Fluctuations in the occurrence of cod in Greenland waters and their possible causes. Cod and climate change: proceedings of a symposium. ICES Mar Sci Symp 198:158-174

$>$ Buch E, Pedersen SA, Ribergaard MH (2004) Ecosystem variability in West Greenland waters. J Northwest Atl Fish Sci 34:13-28

> Byström P, Garcia-Berthou E (1999) Density dependent growth and size specific competitive interactions in young fish. Oikos 86:217-232

Campana SE (1989) Otolith microstructure of three larval gadids in the Gulf of Maine, with inferences on early life history. Can J Zool 67:1401-1410

Campana SE (1996) Year-class strength and growth rate in young Atlantic cod Gadus morhua. Mar Ecol Prog Ser 135:21-26

Campana SE, Hurley PCF (1989) An age-mediated and temperature-mediated growth-model for cod (Gadus morhua) and haddock (Melanogrammus aeglefinus) larvae in the Gulf of Main. Can J Fish Aquat Sci 46:603-613

Campana SE, Frank KT, Hurley PCF, Koeller PA, Page FH, Smith PC (1989) Survival and abundance of young Atlantic cod (Gadus morhua) and haddock (Melanogrammus aeglefinus) as indicators of year-class strength. Can J Fish Aquat Sci 46:s171-s182

Chambers RC, Miller TJ (1995) Evaluating fish growth by means of otolith increment analysis: special properties of individual level longitudinal data. University of South Carolina Press, Columbia, SC

Cottier FR, Nilsen F, Skogseth R, Tverberg V, Skardhamar J, Svendsen H (2010) Arctic fjords: a review of the oceanographic environment and dominant physical processes. In: Howe JA, Austin WEN, Forwick M, Paetzel M (eds) Fjord systems and archives. Spec Publ 344, Geological Society, London, p 35-50

Cushing DH (1990) Plankton production and year-class strength in fish populations: an update of the match/mis- match hypothesis. Adv Mar Biol 26:249-293

Dale T (1984) Embryogenesis and growth of otolith in the cod (Gadus morhu L.). In: Dahl E, Danielssen DS, Moksness E, Solemdal P (eds) The propagation of cod Gadus morhua L. Flødevigen Rapportser, Part 1. Institute of Marine Research, Arendal, p 251-272

Engelstoft JJ (1997) Indenskærs torsk ved Vestgrønland. Book Teknisk Rapport 6. Pinngortitaleriffik (Grønlands Naturinstitut)

Espeland $\mathrm{SH}$, Gundersen AF, Olsen EM, Knutsen $\mathrm{H}$, Gjøsæter J, Stenseth NC (2007) Home range and elevated egg densities within an inshore spawning ground of coastal cod. ICES J Mar Sci 64:920-928

Falk-Petersen S, Hagen W, Kattner G, Clarke A, Sargent J (2000) Lipids, trophic relationships, and biodiversity in Arctic and Antarctic krill. Can J Fish Aquat Sci 57: 178-191

> Fortier L, Leggett WC (1982) Fickian transport and the dispersal of fish larvae in estuaries. Can J Fish Aquat Sci 39: 1150-1163

Fortier L, Leggett WC (1983) Vertical migrations and transport of larval fish in a partially mixed estuary. Can J Fish Aquat Sci 40:1543-1555

Fox J, Weisberg S (2015) Mixed-effects models in R: an appendix to an R companion to applied regression, Vol 1. SAGE Publications, Thousand Oaks, CA

Fox CJ, Taylor M, Dickey-Collas M, Fossum P and others (2008) Mapping the spawning grounds of North Sea cod (Gadus morhua) by direct and indirect means. Proc R Soc B 275:1543-1548

Frank KT, Leggett WC (1985) Reciprocal oscillations in densities of larval fish and potential predators: a reflection of present or past predation? Can J Fish Aquat Sci 42: 1841-1849

Geffen AJ (1995) Growth and otolith microstructure of cod (Gadus morhua L.) larvae. J Plankton Res 17:783-800

Genner MJ, Halliday NC, Simpson SD, Southward AJ, Hawkins SJ, Sims DW (2010) Temperature-driven phenological changes within a marine larval fish assemblage. J Plankton Res 32:699-708

- Green J, Jones R, Brownell S (2004) Age and growth of larval cod and haddock on Georges Bank during 1995 and 1996. Mar Ecol Prog Ser 283:255-268

Greve W, Prinage S, Zidowitz H, Nast J, Reiners F (2005) On the phenology of North Sea ichthyoplankton. ICES J Mar Sci 62:1216-1223

Grønkjær P, Wieland K (1997) Ontogenetic and environmental effects on vertical distribution of cod larvae in the Bornholm Basin, Baltic Sea. Mar Ecol Prog Ser 154: 91-105

Hansen PM (1949) Studies on the biology of the cod in Greenland waters. PhD dissertation, Københavns Universitet

Hastings A, Botsford LW (2006) Persistence of spatial populations depends on returning home. Proc Natl Acad Sci USA 103:6067-6072

> Hiemstra WH (1962) A correlation table as an aid for identifying pelagic fish eggs in plankton samples. J Cons Int Explor Mer 27:100-108

> Huse I (1994) Feeding at different illumination levels in larvae of three marine teleost species: cod, Gadus morhua L., plaice, Pleuronectes platessa L., and turbot, Scophthalmus maximus (L.). Aquacult Res 25:687-695

ICES (2013) Report of the North Western Working Group (NWWG). ICES Headquarters, Copenhagen 
Jakobsen T (1987) Coastal cod in Northern Norway. Fish Res 5:223-234

Jensen AS, Hansen PM (1931) Investigations on the Greenland cod (Gadus callarias L.): with an introduction on the history of the Greenland cod fisheries. Rapp P-V Réun Cons Perm Explor Mer 72:1-41

> Jorde PE, Knutsen H, Espeland SH, Stenseth NC (2007) Spatial scale of genetic structuring in coastal cod Gadus morhua and geographic extent of local populations. Mar Ecol Prog Ser 343:229-237

Kjesbu OS (1994) Time of start of spawning in Atlantic cod (Gadus morhua) females in relation to vitellogenic oocyte diameter, temperature, fish length and condition. J Fish Biol 45:719-735

Knickle DC, Rose GA (2010) Seasonal spawning and windregulated retention-dispersal of early life stage Atlantic cod (Gadus morhua) in a Newfoundland fjord. Fish Oceanogr 19:397-411

Knutsen H, Jorde PE, André C, Stenseth NC (2003) Finescaled geographical population structuring in a highly mobile marine species: the Atlantic cod. Mol Ecol 12: 385-394

Knutsen H, Olsen EM, Ciannelli L, Espeland SH and others (2007) Egg distribution, bottom topography and smallscale cod population structure in a coastal marine system. Mar Ecol Prog Ser 333:249-255

Köster FW, Möllmann C (2000) Trophodynamic control by clupeid predators on recruitment success in Baltic cod? ICES J Mar Sci 57:310-323

Landaeta MF, Castro LR (2006) Larval distribution and growth of the rockfish, Sebastes capensis (Sebastidae, Pisces), in the fjords of southern Chile. ICES J Mar Sci 63: 714-724

Lough RG, Potter DC (1993) Vertical distribution patterns and diel migrations of larval and juvenile haddock Melanogrammus aeglefinus and Atlantic cod Gadus morhua on Georges Bank. Fish Bull 91:281-303

> MacKenzie BR, Kiørboe T (2000) Larval fish feeding and turbulence: a case for the downside. Limnol Oceanogr 45: $1-10$

Mazerolle M (2013) AICcmodavg: model selection and multimodel inference based on (Q)AIC(c). http://CRAN.Rproject.org/package=AICcmodavg

Meekan MG, Fortier L (1996) Selection for fast growth during the larval life of Atlantic cod Gadus morhua on the Scotian Shelf. Mar Ecol Prog Ser 137:25-37

Mountain D, Berrien P, Sibunka J (2003) Distribution, abundance and mortality of cod and haddock eggs and larvae on Georges Bank in 1995 and 1996. Mar Ecol Prog Ser 263:247-260

> Mountain D, Green J, Sibunka J, Johnson D (2008) Growth and mortality of Atlantic cod Gadus morhua and haddock Melanogrammus aeglefinus eggs and larvae on Georges Bank, 1995 to 1999. Mar Ecol Prog Ser 353:225-242

Myksvoll MS, Sundby S, Ådlandsvik B, Vikebø FB (2011) Retention of coastal cod eggs in a fjord caused by interactions between egg buoyancy and circulation pattern. Mar Coast Fish 3:279-294

Myksvoll MS, Sandvik AD, Asplin L, Sundby S (2014) Effects of river regulations on fjord dynamics and retention of coastal cod eggs. ICES J Mar Sci 71:943-956

Nielsen R, Munk P (2004) Growth pattern and growth dependent mortality of larval and pelagic juvenile North Sea cod Gadus morhua. Mar Ecol Prog Ser 278:261-270 Nordeide JT, Johansen SD, Jørgensen TE, Karlsen BO,
Moum T (2011) Population connectivity among migratory and stationary cod Gadus morhua in the Northeast Atlantic-A review of 80 years of study. Mar Ecol Prog Ser 435:269-283

Oksanen J, Blanchet F, Kindt R, Legendre P and others (2012) vegan: community ecology package. https://cran. r-project.org/web/packages/vegan/index.html

Otterlei E, Nyhammer G, Folkvord A, Stefansson SO (1999) Temperature- and size-dependent growth of larval and early juvenile Atlantic cod (Gadus morhua): a comparative study of Norwegian coastal cod and northeast Arctic cod. Can J Fish Aquat Sci 56:2099-2111

> Otterlei E, Folkvord A, Nyhammer G (2002) Temperature dependent otolith growth of larval and early juvenile Atlantic cod (Gadus morhua). ICES J Mar Sci 59:401-410

Ouellet P, Lambert Y, Berube I (2001) Cod egg characteristics and viability in relation to low temperature and maternal nutritional condition. ICES J Mar Sci 58: 672-686

Pinheiro J, Bates D, DebRoy S, Sarkar D and R Core Team (2014) nlme: linear and nonlinear mixed effects models. http://CRAN.R-project.org/package=nlme

Plant RE (2012) Spatial data analysis in ecology and agriculture using R. CRC Press Boca Raton, FL

> Poloczanska ES, Brown CJ, Sydeman WJ, Kiessling W and others (2013) Global imprint of climate change on marine life. Nat Clim Change 3:919-925

R Core Team (2014) R: a language and environment for statistical computing. R Foundation for Statistical Computing, Vienna

Riisgaard K, Swalethorp R, Kjellerup S, Juul-Pedersen T, Nielsen TG (2014) Trophic role and top-down control of a subarctic protozooplankton community. Mar Ecol Prog Ser 500:67-82

Robichaud D, Rose GA (2004) Migratory behaviour and range in Atlantic cod: inference from a century of tagging. Fish Fish 5:185-214

Rose GA, deYoung B, Kulka DW, Goddard SV, Fletcher GL (2000) Distribution shifts and overfishing the northern cod (Gadus morhua): a view from the ocean. Can J Fish Aquat Sci 57:644-663

Smidt ELB (1979) Annual cycles of primary production and of zooplankton at Southwest Greenland. Greenland Bioscience 1

Stein M, Borovkov VA (2004) Greenland cod (Gadus morhua): modeling recruitment variation during the second half of the 20th century. Fish Oceanogr 13:111-120

> Steinarsson A, Björnsson B (1999) The effects of temperature and size on growth and mortality of cod larvae. J Fish Biol 55:100-109

Storr-Paulsen M, Wieland K, Hovgard H, Ratz HJ (2004) Stock structure of Atlantic cod (Gadus morhua) in West Greenland waters: implications of transport and migration. ICES J Mar Sci 61:972-982

Suthers IM, Sundby S (1993) Dispersal and growth of pelagic juvenile Arcto-Norwegian cod (Gadus morhua), inferred from otolith microstructure and water temperature. ICES J Mar Sci 50:261-270

Svendsen H, Thompson R (1978) Wind-driven circulation in a fjord. J Phys Oceanogr 8:703-712

> Swalethorp R, Kjellerup S, Malanski E, Munk P, Nielsen TG (2014) Feeding opportunities of larval and juvenile cod (Gadus morhua) in a Greenlandic fjord: temporal and spatial linkages between cod and their preferred prey. Mar Biol 161:2831-2846 
Swalethorp R, Malanski E, Dalgaard Agersted M, Nielsen TG, Munk P (2015) Structuring of zooplankton and fish larvae assemblages in a freshwater-influenced Greenlandic fjord: influence from hydrography and prey availability. J Plankton Res 37:102-119

Theilacker GH (1980) Changes in body measurements of larval northern anchovy, Engraulis mordax, and other fishes due to handling and preservation. Fish Bull 78: 685-692

Theilacker GH, Lasker R (1974) Laboratory studies of predation by euphausiid shrimps on fish larvae. In: Blaxter JHS (ed) The early life history of fish. Springer, p 287-299

Therkildsen NO, Hemmer-Hansen J, Hedeholm RB, Wisz MS and others (2013) Spatiotemporal SNP analysis reveals pronounced biocomplexity at the northern range margin of Atlantic cod Gadus morhua. Evol Appl 6: 690-705

Thompson BM, Riely JD (1981) Egg and larval development studies in the North Sea cod Gadus morhua. Rapp P-V Réun Cons Int Explor Mer 178:553-559

Torgersen $\mathrm{T}$ (2001) Visual predation by the euphausiid Meganyctiphanes norvegica. Mar Ecol Prog Ser 209: 295-299

Editorial responsibility: Stylianos Somarakis, Heraklion, Greece
Van der Meeren T, Moksness E (2003) Growth and mortality patterns evaluated from otolith microstructure in Atlantic cod Gadus morhua larvae reared on different feeding regimes in mesocosms. Mar Ecol Prog Ser 264: 95-107

Vikebø F, Sundby S, Ådlandsvik B, Fiksen $\varnothing$ (2005) The combined effect of transport and temperature on distribution and growth of larvae and pelagic juveniles of Arcto-Norwegian cod. ICES J Mar Sci 62:1375-1386

Vollset KW, Folkvord A, Browman HI (2011) Foraging behaviour of larval cod (Gadus morhua) at low light intensities. Mar Biol 158:1125-1133

Wieland K, Hinrichsen HH, Gronkjaer P (2000) Stagespecific mortality of Baltic cod (Gadus morhua L.) eggs. J Appl Ichthyol 16:266-272

Wiseman WJ, Garvine RW (1995) Plumes and coastal currents near large river mouths. Estuaries 18:509-517

Wood SN (2006) Generalized Additive Models: an introduction with R. Chapman and Hall/CRC, Boca Raton, FL

Wroblewski J, Neis B, Gosse K (2005) Inshore stocks of Atlantic cod are important for rebuilding the east coast fishery. Coast Manage 33:411-432

Submitted: November 13, 2015; Accepted: June 22, 2016 Proofs received from author(s): July 29, 2016 